with accommodation for an Eskimo crew of four; laboratory and two-berth cabin; cargo-room; engine-room; galley and toilet, and saloon. Heating is by hot-water radiators, lighting by electricity. There is accommodation for a total complement of eight.

The equipment includes a fully equipped laboratory; an echo-sounder with 75- and 300-fathom scales; a radiophone; a two-drum engine-driven winch, with 275 fathoms of wire on each drum, running through fair leads to gallowsframes for otter and beam trawling; and two hydrographic winches with 500 and $1000 \mathrm{~m}$. of wire respectively.

\title{
THE SNOWMOBILE
}

[Summarized from notes in Motor, Vol. 94, 19 January 1949, p. 695, and Arctic Circular, Vol. 1, No. 4, 1948, p. 41.]

In 1926 an experimental half-tracked vehicle; steered by skis and propelled by caterpillar tracks, was designed and built by J. A. Bombardier to operate on snow-bound roads in northern Canada. The vehicle, known as the Snowmobile, was later produced in large numbers for doctors and commercial firms, and between 1939 and 1945 was used extensively by the armed forces.

The power unit of the civilian Snowmobile is a 115 Chrysler T120 engine, located at the rear, driving the bogie axle through a standard Chrysler gear-box. The rear axle carries two large sprockets to drive the caterpillar tracks, which on each side run over four wheels fitted with 450 by 16 -in. tyres. The forward end of the vehicle is mounted on skis, $12 \mathrm{in}$. wide by $60 \mathrm{in}$. long, by means of which it is steered. Spring action on the steering skis is achieved by means of two vertical shock absorbers, short lengths of chain being fastened from these to a rocker arm on the skis. The same type of springing action is used for body suspension, except that the shock absorbers are installed horizontally. To ensure that no part of the mechanism can become clogged by snow, the bottom is planked, and the braking system, which operates on the propeller shaft, and the brake and clutch operating rods are installed between the bottom planking and the floor-boards. This has the advantage that all repairs can be effected from inside the body by lifting the floor-boards or by opening the doors of the engine compartment and working on the engine in the engineroom.

Body weight is kept to a minimum: plywood is used throughout, and the overall weight is $3400 \mathrm{lb}$. The full load consists of twelve passengers or $2000 \mathrm{lb}$. of goods. Snow pressure over the 5000 sq.in. of bearing surface is less than $\frac{3}{4} \mathrm{lb}$. per sq.in. Internal heating is provided by circulating water from the engine radiator directly through heating radiators inside the body. Each heating radiator is fitted with a control valve, so that internal temperature can be adjusted. When the radiators are shut off, water circulates through the enginecooling system in the normal way.

Since 1945, the military Snowmobile has been developed largely as a result of lessons learnt during Exercise "Musk-Ox" in 1946. The Penguin Mark I then in use proved itself capable of traversing either frozen or thawing terrain, but 
there were many undesirable features of design and shortcomings in performance. The main improvements of the Penguin Mark II were increased mechanical reliability, personal comfort, and weather protection. The Mark II is equipped with wireless and carries five men with their essential personal survival equipment. It is heated, weather-proofed, and will float in water. It is capable of towing heavy loads and in spite of its great weight the wide tracks permit it to travel over surfaces where a man without snow shoes would sink in snow or mud.

\section{UNITED STATES AIR FORCE RESCUE ACTIVITIES IN ALASKA}

[Based on a note by Wilbur Forrest in the New York Herald Tribune of 14 December 1947 and information in Alaska Sportsman, Vol. 16, No. 7, 1950, p. 21, and The Times of 30 March 1950.]

An interesting consequence of United States Air Force activity in the Arctic during recent years has been the development of techniques to rescue airmen forced down and stranded in polar regions. This work has been carried out mainly by the specially trained 10th Air Search and Rescue Squadron, commanded by Colonel Bernt Balchen, U.S.A.F. The squadron, which is based on the Elmendorff Field at Anchorage, Alaska, is equipped with a miscellaneous collection of aircraft suitable for different kinds of rescue work. Detachments are based on Adak, in the Aleutian Islands; Cold Bay, at the end of the Alaskan peninsula; and on Ladd Field near Fairbanks. In addition to multi-engined amphibious aircraft and small L-5s, the squadron is equipped with DC-3s, fitted with a combination of skis and wheels, and gliders for landing on especially rough terrain.

A special unit of the squadron has been practising rescue methods on the pack ice off Point Barrow, and small L-5 aircraft have successfully landed 200 miles north of the mainland. On 21 and 22 March 1950 a C-47 aircraft, piloted by Lieutenant-Colonel Eugene $O$. Strause, made two successful landings on the pack ice about 100 miles north of Barter Island. On both days the aircraft, fitted with a combination of skis and wheels, was preceded in its landings by a glider, which was afterwards picked up and towed back to Barter Island.

In September 1947, Major-General J. H. Atkinson, commanding the United States Air Force in Alaska, decided to open a training establishment where airmen under his command might learn how to survive if they were forced down in arctic conditions. The school, known as the Arctic Polar Survival and Indoctrination School, was established at Nome in the winter of 1947-48, and placed under the command of Captain Harold Lovell Strong, United States Army. Airmen are given a six-day instructional course, consisting of three days on barren tundra and three days on sea ice. The course aims to give psychological assurance to airmen that rescue work is possible even in very adverse circumstances. It is emphasized that with the normal amount of equipment and common sense, and the proper utilization of such natural resources as may be available, they can expect to survive the experience. 